\title{
PENGARUH FLYPAPER EFFECT PADA DANA ALOKASI UMUM (DAU) TERHADAP KINERJA KEUANGAN PEMERINTAH DAERAH KOTA BIMA PROVINSI NUSA TENGGARA BARAT (NTB)
}

\author{
Savita Fintari
}

Universitas Terbuka, Indonesia savitafintari@gmail.com

Submitted: 8 Juli 2020

Revised: 17 Agustus 2020

Accepted: 10 November 2020

\begin{abstract}
The paper aimed to analyze the influence of the flypaper effect on general allocation funds (DAU) to the financial performance in Bima, West Nusa Tenggara province . Variables used in this research were the general allocation fund (DAU) as independent variabel and the financial performance of local government as dependent variable. This research used a quantitative method. Census was conducted in Badan Pengelolaan Keuangan dan Aset Daerah (BPKAD) Bima. The data was analyzed using SPSS version 16.o. The finding of the study showed that the flypaper effect of the general allocation funds and the financial performance of local government had a negative and significant relation. The influence of general allocation funds to the financial performance of local government in Bima was $41.2 \%$ and the rest $58.8 \%$ was the changing of financial performance of local government caused by another variable which was not examined.
\end{abstract}

Keywords: Influence, flypaper effect, unconditional grants, the financial performance of local government

\section{PENDAHULUAN}

Sejatinya implementasi otonomi daerah ditujukan untuk meningkatkan pelayanan dan kesahteraan masyarakat, meringankan beban pemerintah pusat serta memberikan kesempatan kepada pemerintah daerah untuk memberdayakan potensi sumber daya alam dan masyarakat di daerah. Sehingga pelaksanaan otonomi daerah memerlukan pembiayaan yang cukup besar dan sudah seharusnya dipikul serta menjadi tanggung jawab daerah sehingga daerah tidak dapat lagi berpangku tangan hanya mengandalkan kucuran dana dari pemerintah pusat. Pada kenyataannya PAD di kota dan kabupaten tidak cukup mendanai kebijakan kesejahteraan masyarakatnya. Sedangkan APBD di kota/ kabupaten 80 persen merupakan Dana Alokasi Umum (DAU) dari pusat. Artiya hanya 20 persen APBD berasal dari Pendapatan Asli Daerah (PAD). Mayoritas dana harus disupplai dari pusat. Ini juga menunjukkan bahwa skala ekonomi jelas tidak baik di kota dan kabupaten. Belum lagi belanja di tingkat di kota dan kabupaten sekitar 70-80 persen ditujukan untuk belanja pegawai. Artinya, hanya 20 persen untuk belanja publik atau infrastruktur (Kurnia, 2013).

Fenomena yang timbul dari pelaksanaan otonomi daerah di Indonesia salah satunya adalah berupa ketergantungan yang tinggi pemerintah daerah terhadap pemerintah pusat. Hal ini jelas tergambar pada nilai transfer DAU yang diberikan pemerintah pusat kepada pemerintah daerah lebih tinggi dan kurang memperhatikan kemampuan daerah dalam mengoptimalkan potensi yang dimiliki pemerintah daerah. Akibatnya pemerintah daerah selalu menuntut transfer yang besar dari pemerintah pusat dan bukan memaksimalkan kapasitas fiskal daerah (potensi fiskal). Ketergantungan ini 
terjadi saat pemerintah merespon belanja lebih banyak atau boros dengan mengguanakan dana transfer (grants) yang diproyeksikan dengan DAU daripada menggunakan kemampuan sendiri, diproyeksikan dengan PAD. Maka, fenomena tersebut disebut dengan flypaper effect (Maimunah, 2006).

Ironisnya, alokasi dana transfer ke daerah kabupaten/kota pada umumnya lebih banyak didasarkan pada aspek belanja tetapi kurang memperhatikan kemampuan pengumpulan pajak lokal sehingga penerimaan pendapatan asli daerah pada lahan pajak menjadi kurang. Transfer pemerintah pusat yang khususnya didominasi oleh transfer tak bersyarat (Unconditional Grant) yaitu DAU dan DBH juga masih berpengaruh dalam pengeluaran dan belanja pembangunan yang ada di Kota Bima. Hal ini ditandai dengan tingginya porsi penerimaan transfer tak bersyarat (Uncondotional Grant) dari pada Penerimaan Pendapatan Asli Daerah (PAD) dan transfer bersyarat (Conditional Grant) atau pendapatan lain-lainnya. Terbukti dengan proporsi PAD, DAU dan pendapatan lain-lain yang sah Pemerintah Kota Bima Tahun 2015 - 2017 di tunjukkan pada Tabel 1.
Berdasarkan pada table 1 di atas, diketahui bahwa komposisi pendapatan Kota Bima Tahun 2015 - 2017 secara umum cenderung menunjukkan terjadinya peningkatan dan pendapatan Kota Bima didominasi oleh pendapatan yang bersumber dari dana perimbangan. Pada tahun 2015, pemerintah pusat memberikan dana perimbangan sebesar 552.406 Milyar dan meningkat dari tahun ke tahun sampai pada tahun 2017. Dengan kenaikan sebesar 5\% pada tahun 2014, lalu pada tahun 2016 dana perimbangan mengalami peningkatan sebesar $18 \%$ kemudian pada Tahun 2017 meningkat sebesar 26\% sementara porsi terbesar pada dana perimbangan dipemerintah Kota Bima adalah dana alokasi umum. Jelas tergambar pada tabel diatas dana alokasi umum dari tahun 2015 hingga tahun 2017 mengalami rata-rata peningkatan sebesar 3,86\%. Hal serupa dinyatakan oleh (Sidiq, 2016) "Disaat transfer yang diperoleh besar maka pemerintah daerah berusaha agar periode berikutnya transfer yang diperoleh tetap besar sehingga transfer meningkat ditahun berikutnya".

Untuk mengetahui bagaimana bentuk perbandingan mengenai pendapatan daerah dan

Tabel 1. Komposisi Pendapatan Daerah Kota Bima T.A 2015 - 2017 (dalam milyaran)

Sumber : Kota Bima Dalam Angka, 2018

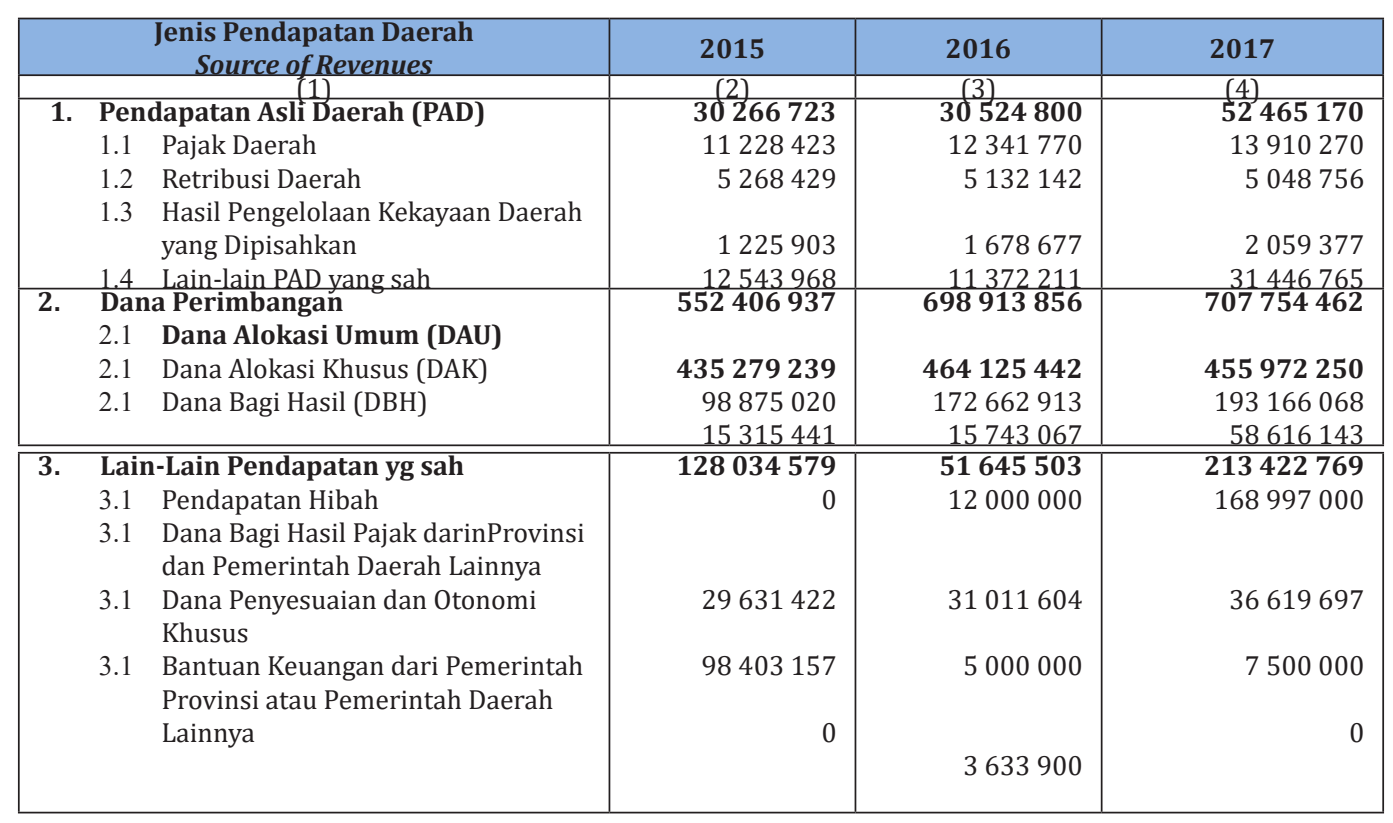


transfer dari pemerintah pusat pusat maka perhatikan grafik perbandingan pendapatan daerah Pemerintah Kota Bima yang akan ditampilkan pada gambar 1 di bawah ini.

Gambar 1. Perbandingan Unsur Pendapatan Kota Bima Provinsi Nusa Tenggara Barat (NTB) T.A 2015-2017

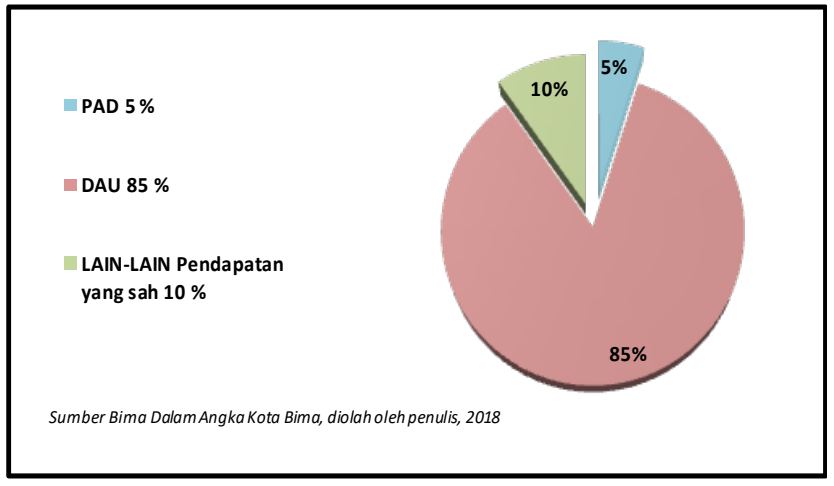

Gambar diatas menunjukkan bahwa Kota Bima tergolong daerah yang relatif kurang mandiri dan masih bergantung pada pemerintah pusat dalam hubungan finansial. Hal ini ditandai dengan adanya dominasi dana perimbangan yaitu sebesar $85 \%$ pada penerimaan pendapatan daerah Kota Bima dari pada PAD yang hanya menyumbang $5 \%$ saja. Gambaran proporsi diatas menunjukkan adanya indikasi terjadinya flypaper effect. Berdasarkan uraian di atas maka penulis tertarik melakukan penelitian dengan judul "Pengaruh Flypaper Effect Pada pada Dana Alokasi Umum (DAU) Terhadap Kinerja

Keuangan Pemerintah Daerah Kota Bima Provinsi Nusa Tenggara Barat (NTB)”.

Dengan mengacu pada rumusan masalah di atas maka adapun yang menjadi tujuan penelitian ini, adalah:

1. Untuk mengetahui apakah flypaper effect terjadi di Kota Bima.

2. Untuk mengetahui apakah flypaper effect pada Dana Alokasi Umum (DAU) berpengaruh terhadap kinerja keuangan Pemerintah Daerah Kota Bima.

3. Untuk mengetahui bagaimana pengaruh flypaper effect pada Dana Alokasi Umum (DAU) terhadap kinerja keuangan Pemerintah Daerah Kota Bima.

\section{Kajian Literatur dan Teori}

MenurutSukriy dan Halim (2003), definisi flypaper effect merupakan respon pemerintah daerah berbeda untuk transfer dan pendapatan daerahnya sendiri. Menurut Maimunah (2006) flypaper effect merupakan suatu kondisi yang terjadi saat pemerintah merespon belanja lebih banyak atau boros dengan mengguanakan dana transfer (grants) yang diproyeksikan dengan DAU (Dana Alokasi Umum) daripada menggunakan kemampuan sendiri, diproyeksikan dengan PAD (Pendapatan Asli Daerah).

Kuncoro (2007) mendefinisikan flypaper effect adalah gejala dimana transfer meningkatkan pengeluaran konsumsi barang publik, tetapi tidak menjadi subsitusi bagi pajak daerah. Berdasarkan uraian diatas, dapat dipahami bahwa yang dimaksud dengan flypaper effect merupakan suatu kecenderungan pemerintah daerah merespon belanja lebih besar pada dana transfer yang diberikan oleh pemerintah pusat daripada pendapatan daerahnya sendiri. Dalam hal ini, pemerintah cenderung boros pada dana transfer tidak bersyarat yang khususnya pada Dana Alokasi Umum (DAU) daripada pendapatan yang dihasilkan oleh pemerintah daerah sendiri.

\section{Transfer}

\section{a.Transfer Bersyarat}

Menurut Shah (1991:4), conditional grants dimaksudkan untuk menyediakan insentif pemerintah untuk menjalankan program atau aktifitas tertentu. Transfer (grants) ini dapat diberikan secara berkala atau sesuai mandat yang diberikan atau dapat digunakan sewaktu-waktu (adhoc). Transfer bersyarat (conditional grants) secara tipikal menentukan jenis pengeluaran yang akan dibiayai berdasarkan kondisi tertentu. Menurut Azwardi (2007), transfer bersyarat di Indonesia biasanya dalam bentuk Dana Alokasi Khusus (DAK). Conditional grants terdiri dari 
bantuan penyeimbang (matching grants) dan bantuan bukan penyeimbang (non-matching grants).

\section{b.Transfer Tidak Bersyarat}

Transfer tidak bersyarat (Unconditional grants) yang sering disebut dengan bantuan tak bersyarat menurut (Azwardi, 2007:4) di Indonesia berbentuk Dana Alokasi Umum (DAU) dan Dana Bagi Hasil (DBH). Menurut koleman (1996) dalam Purnomo (2011), Transfer Tidak Bersyarat (Unconditional Grants) merupakan transfer yang diberikan oleh pemerintah pusat kepada pemerintah daerah tanpa persyaratan tertentu dan pada umumnya transfer ini diberikan kepada pemerintah pusat yang berkaitan dengan usahausaha produktif untuk peningkatan investasi pada badan usaha yang ada di daerah.

\section{Kinerja Keuangan Pemerintah Daerah}

Menurut Syafri (2008:213) kinerja keuangan pemerintah daerah merupakan salah satu ukuran yang dapat digunakan untuk melihat kemampuan daerah dalam menjalankan otonomi daerah. Selanjutnya pengukuran kinerja diartikan sebagai suatu indikator keuangan dan non keuangan dari suatu pekerjaan yang dilaksanaan dari sebuah aktivitas dari proses suatu unit organisasi.

Salah satu alat untuk mengukur kinerja keuangan pemerintah daerah adalah dengan melakukan analisis rasio keuangan terhadap APBD yang telah ditetapkan dan dilaksanakan (Halim, 2002:126). Adapun analisis rasio keuangan yang digunakan dalam penelitian ini adalah rasio kemandirian keuangan, rasio efektivitas terhadap pendapatan asli daerah, rasio ketergantungan.

\section{Kinerja Keuangan Pemerintah Daerah}

Menurut Halim (2007:150) bahwa "membagi rasio kedalam beberapa kelompok rasio yang dapat dijadikan tolak ukur menilai kinerja keuangan pemerintah daerah yang bersumber dari APBD”. Antara lain, adalah:
a.Rasio Kemandirian Keuanagan Daerah (RKKD)

Rasio kemandirian keuangan daerah Menunjukkan kemampuan pemerintah daerah dalam membiayai sendiri kegiatan pemerintahan, pembangunan, pelayanan kepada masyarakat yang telah membayar pajak dan retribusi sebagai sumber pendapatan yang dibutuhkan oleh daerah. Adapun Formula untuk mengukur rasio kemandirian keuangan daerah sebagai berikut (Halim, 2004:150) :

Rasio Kemandirian $=\frac{\text { Pendapatan Asli Daerah (PAD) }}{\text { Bantuan Pemerintah Pusat } / \text { Provinsi }} \times 100 \%$

Dengan melihat tingkat dan pola hubungan pada tabel 2 berikut ini:

Tabel 2. Pola Hubungan dan Tingkat

Kemandirian Daerah

\begin{tabular}{|c|c|c|}
\hline $\begin{array}{c}\text { Kemampuan } \\
\text { Daerah }\end{array}$ & Kemandirian (\%) & Pola Hubungan \\
\hline Rendah sekali & $0-25$ & Instruktif \\
\hline Rendah & $25-50$ & Konsultatif \\
\hline Sedang & $50-75$ & Partisipatif \\
\hline Tinggi & $75-100$ & Delegatif \\
\hline
\end{tabular}

b.Rasio Efektifitas terhadap Penapatan Asli Daerah (PAD)

Rasio efektivitas terhadap PAD menggambarkan kemampuan pemerintah daerah dalam merealisasikan pendapatan asli daerah (PAD) yang direncanakan dan dibandingkan dengan target yang telah ditetapkan berdasarkan potensi daerah yang riil Halim (2007:234). Untuk mengukur rasio efektivitas PAD ini dapat menggunakan formula sebagai berikut :

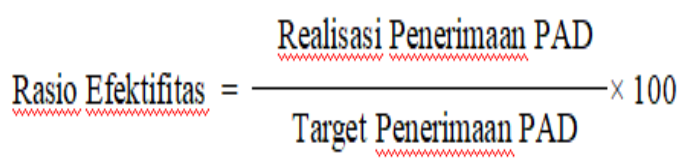

Dengan kriteria efektivitas kinerja keuangan pemerintah daerah yang dapat dilihat pada tabel 3 . 
Tabel 3. Kriteria Efektivitas Kinerja Keuangan

Sumber: Kepmendagri No.690.900.327 tahun 1996

\begin{tabular}{|c|c|}
\hline Presentase Efektifitas & Pola Hubungan \\
\hline$>\mathbf{1 0 0}$ & Sangat Efektif \\
\hline $\mathbf{9 0 - 1 0 0}$ & Efektif \\
\hline $\mathbf{8 0 - 9 0}$ & Cukup Efektif \\
\hline $\mathbf{6 0 - 8 0}$ & Kurang Efektif \\
\hline$<\mathbf{6 0}$ & Tidak Efektif \\
\hline
\end{tabular}

c.Rasio Ketergantungan Keuangan Daerah

Rasio ketergantungan adalah rasio yang digunakan ketika ingin melihat seberapa besarkah tingkat ketergantungan pemerintah daerah dalam menggunakan dana-dana yang diberikan pemerintah pusat. Tingkat ketergantungan daerah dapat diukur dengan rasio antara total penerimaan daerah dengan total Dana Perimbangan. Untuk menghitung rasio ketergantungan keuangan daerah dapat menggunakan formula sebagai berikut:

Rasio Ketergantungan $=$ Total Pendapatan Daerah / Total Dana Transfer $\times 100 \%$

Kriteria penilaian ketergantungan keuangan daerah dapat dilihat pada Tabel 4 berikut ini:

Tabel 4. Kriteria Penilaian Ketergantungan Keuangan Daerah

Sumber : Tim Litbang Depdagri-Fisipol UGM, 1991

\begin{tabular}{|c|c|}
\hline $\begin{array}{c}\text { Persentase PAD terhadap Total } \\
\text { Penerimaan Non Subsidi }\end{array}$ & $\begin{array}{c}\text { Ketergantungan } \\
\text { Keuangan Daerah } \\
\text { Sangat Rendah }\end{array}$ \\
\hline $\mathbf{0 , 0 0 - 1 0 , 0 0}$ & Rendah \\
\hline $\mathbf{1 0 , 0 1 - 2 0 , 0 0}$ & Sedang \\
\hline $\mathbf{2 0 , 0 1 - 3 0 , 0 0}$ & Cukup \\
\hline $\mathbf{3 0 , 0 1 - 4 0 , 0 0}$ & Tinggi \\
\hline $\mathbf{4 0 , 0 1 - 5 0 , 0 0}$ & Sangat Tinggi \\
\hline$>\mathbf{5 0 , 0 0}$ & \\
\hline
\end{tabular}

Kerangka Analisis

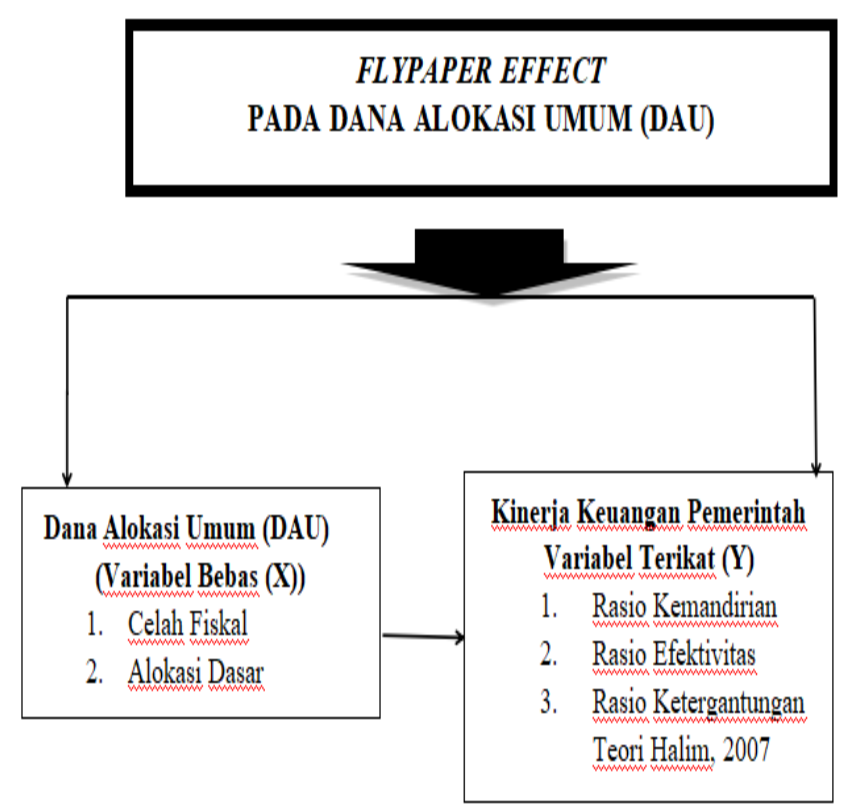

Gambar 2. Kerangka Analisis

\section{Metode Penelitian}

Penelitian ini merupakan studi kasus yang dilakukan di Badan Pengelolaan Keuangan dan Aset Daerah Kota Bima yang merupakan salah satu kota di Provinsi Nusa Tenggara Barat (NTB). Metode penelitian dalam penelitian ini menggunakan metode kuantitatif dan terdiri dari satu variabel independen dan satu variabel dependen yang mana dalam penelitian ini DAU menjadi variabel independen dan kinerja keuangan pemerintah merupakan variabel dependen. Paradigma yang digunakan dalam penelitian ini adalah paradigma sederhana.

Metode pengumpulan data menggunakan berbagai sumber data yaitu data primer dan data skunder yaitu LRA Pemerintah Kota Bima 2015-2017 dan Bima Dalam Angka Tahun 2017. Teknik pengumpulan data dalam penelitian ini menggunakan penyebaran kuesioner secara langsung pada pegawai negeri di BPKAD Kota Bima. Metode analisis data dalam penelitian kuantitatif menggunakan statistik deskripsi yang merupakan analisis yang dilakukan berdasarkan jawaban yang diperoleh dari responden dalam 
bentuk keterangan dalam hal ini meliputi karateristik responden terhadap variabel yang dinilai.Penelitianinimenggunakanujipersyaratan regresi yang meliputi uiji multikolinearitas, uji autokorelasi dan uji heteroskedasitas. Dan untuk mengetahui pengaruh variabel bebas dengan variabel dependen maka digunakan analisis regresi liner dengan bantuan program SPSS 16.0 dan panduan analisis Siregar (2013).

\section{PEMBAHASAN}

\section{Rasio Kemandirian Keuangan Daerah}

Rasio Kemandirian daerah yang bertujuan untuk menggambarkan ketergantungan daerah terhadap sumber dana eksternal dan menggambarkan tingkat partisipasi masyarakat dalam pembangunan daerah. Dalam hal ini pemerintah sangat di tuntut untuk meningkatkan Pendapatan Asli Daerah guna membiayai kebutuahan daerah, pembanguanan daerah serta pelayanan kepada masyarakat yang telah membayar pajak dan retribusi sebagai sumber pendapatan yang diperlukan daerah. Rasio Kemandirian Keuangan Daerah Kota Bima Periode Tahun 2015-2017 ditunjukkan pada tabel 5 .

Tabel 5. Rasio Kemandirian Keuangan Daerah (RKKD) Kota Bima Periode Tahun 2015-2017

Sumber: Data Skunder diolah, 2018

\begin{tabular}{c|c|c|c|c}
$\begin{array}{c}\text { Tahun } \\
\text { Anggaran }\end{array}$ & $\begin{array}{c}\text { Pendapatan } \\
\text { Asli Daerah } \\
\text { (Rp) }\end{array}$ & $\begin{array}{c}\text { Total } \\
\text { Penerimaan } \\
\text { APBD tanpa } \\
\text { subsidi (Rp) }\end{array}$ & $\begin{array}{c}\text { RKKD } \\
(\%)\end{array}$ & Ket \\
\hline 2015 & 30.266 .723 & 552.406 .937 & 6,95 & Instruktif \\
\hline 2016 & 30.524 .800 & 698.913 .856 & 6.57 & Instruktif \\
\hline 2017 & 52465170 & 707754462 & 11,50 & Instruktif
\end{tabular}

Berdasarkan hasil perhitungan pada tabel 5 menunjukkan bahwa Rasio Kemandirian Keuangan Kota Bima TA 2015 hingga TA 2017 tergolong rendah dan membentuk pola hubungan "INSTRUKTIF". Hal tersebut jelas terlihat dari persentase rasio kemandirian keuangan Kota
Bima yang tidak pernah lebih dari 10\% sehingga belum dapat dikatakan daerah yang mandiri dan belum mampu melaksanakan otonomi daerah secara financial. Oleh karena itu perlu adanya terobosan-terobosan baru untuk meningkatkan pendapatan asli daerah agar rasio kemandirian Kota Bima mengalami peningkatan yang signifikan.

1.Rasio Efektifitas Pendapatan Asli Daerah

Rasio efektifitas digunakan untuk menggambarkan kemampuan pemerintah daerah dalam merealisasikan PAD yang telah direncanakan dibandingkan dengan target awal yang ditetapkan berdasarkan potensi rill daerah. Rasio Efektifitas Pendapatan Asli Daerah Kota Bima Tahun 2015-2017 ditunjukkan pada tabel 6.

Tabel 6. Rasio Efektifitas Pendapatan Asli Daerah (PAD) Pemerintah Daerah Kota Bima Tahun 2015-2017

Sumber: Data Skunder diolah, 2018

\begin{tabular}{|c|c|c|c|c|}
\hline $\begin{array}{c}\text { Tahun } \\
\text { Anggaran }\end{array}$ & $\begin{array}{c}\text { Realisasi } \\
\text { PAD } \\
\text { (Rp) }\end{array}$ & $\begin{array}{c}\text { Target } \\
\text { PAD } \\
\text { (Rp) }\end{array}$ & $\begin{array}{c}\text { RE } \\
(\%)\end{array}$ & Keterangan \\
\hline 2015 & 30.266 .723 & 28.392 .440 & 106,6 & Sangat Efektif \\
\hline 2016 & 30.524 .800 & 31.100 .000 & 98,1 & Cukup Efektif \\
\hline 2017 & 52465170 & 32.153 .669 & 163,1 & Sangat Efektif \\
\hline
\end{tabular}

Berdasarkan perhitungan pada tabel 6 menunjukkan presentase rasio efektifitas Kota Bima mengalami penuranan dan kenaikan. Pada tahun 2016 persentasi rasio efektifitas Kota Bima sebesar 98,1\% dan kemudian meningkat pada tahun 2017 sebesar 163,1\%. Sehingga menurut uraian dan hasil perhitungan rasio efektifitas Kota Bima tergolong sangat efektif.

\section{Rasio Ketergantungan}

Rasio ketergantungan daerah adalah untuk mengukur tingkat kemampuan daerah 
dalam membiayai aktifitas pembangunan melalui pengoptimalisi PAD, yang mana diukur dengan perbandingan antara PAD dan total penerimaan APBD tanpa subsidi (Dana Perimbanagan). Dari hasil analisis rasio ketergantungan diperoleh data ketergantungan keuangan daerah Kota Bima Tahun 2015-2017 sebagai berikut:

\section{Tabel 7. Rasio Ketergantungan Keuangan Kota Bima Tahun 2015-2017}

Sumber: Data Skunder diolah, 2018

\begin{tabular}{|c|c|c|c|c|}
\hline $\begin{array}{c}\text { Tahun } \\
\text { Anggaran }\end{array}$ & $\begin{array}{c}\text { Dana } \\
\text { Perimbangan } \\
(\mathbf{R p})\end{array}$ & $\begin{array}{c}\text { Total } \\
\text { Penerimaan } \\
\text { Daerah } \\
(\mathbf{R p})\end{array}$ & $\begin{array}{c}\text { Rasio } \\
\text { Keter- } \\
\text { gantungan } \\
(\mathbf{\%})\end{array}$ & Ket. \\
\hline 2015 & 552.406 .937 & 710.708 .239 & 77,7 & $\begin{array}{c}\text { Sangat } \\
\text { Tinggi }\end{array}$ \\
\hline 2016 & 698.913 .856 & 781.084 .159 & 89,4 & $\begin{array}{c}\text { Sangat } \\
\text { Tinggi }\end{array}$ \\
\hline 2017 & 707.754 .462 & 973.642 .401 & 72,6 & $\begin{array}{c}\text { Sangat } \\
\text { Tinggi }\end{array}$ \\
\hline
\end{tabular}

Berdasarkan tabel 7 di atas, rata-rata tingkat ketergantungan keuangan daerah Kota Bima adalah sebesar 79,9\%, sehingga dapat diklasifikasikan menurut kriteria penilaian ketergantungan keuangan daerah adalah sangat tinggi. Terlebih lagi pada tahun 2016, rasio ketergantungan mencapai $89,4 \%$ dikarenakan pada tahun tersebut penerimaan yang bersumber dari dana perimbangan mengalami kenaikan sebesar Rp. 146.506.919.000 dari tahun sebelumnya. Hal ini menggambarkan bahwa tingkat ketergantungan Pemerintah Kota Bima sangat Tinggi kepada Pemerintah Pusat.

\section{Statistik Deskriptif}

1.Uji Persyaratan Regresi (uji Asumsi Klasik)

a.Uji Linieritas

Beradasarkan hasil analisis data uji linieritas dengan menggunakan bantuan SPSS 16.o for windows dapat diketahui bahwa masingmasing variabel Flypaper Effect pada Dana Alokasi Umum (DAU) dan variabel Kinerja
Keuangan Pemerintah Kota Bima penelitian dapat dinyatakan memiliki hubungan yang linier karena nilai signifikan setiap variabel lebih besar (>) 0.05 .

Tabel 8. Ringkasan Uji Linieritas dengan Program SPSS 16.0 for windows

Sumber: Output SPSS 16.o tahun 2018

\begin{tabular}{cc|ccc}
\hline No & $\begin{array}{c}\text { Nama } \\
\text { Variabel }\end{array}$ & $\begin{array}{c}\text { Jenis } \\
\text { Variabel }\end{array}$ & Signifikan & Keterangan \\
\hline 1 & Flypaper Effect & Independen & 0.331 & Linier \\
\hline & Kinerja & Dependen & 0.514 & Linier \\
\hline
\end{tabular}

Berdasarkan nilai signifikansi dari output diatas, diperoleh nilai signifikansi flypaper effect $=0.331>0.05$ dan kinerja keuangan $=0.514$ $>0.05$ menyatakan bahwa terdapat hubungan linear secara signifikan antara flypaper effect pada dana alokasi umum dan kinerja keuangan Pemerintah Daerah Kota Bima.

b. Normalitas

Berdasarkan hasil analisis data uji normalitas masing-masing variabel penelitian dengan mengamati taraf signifikan masingmasing variable penelitian maka dinyatakan data berdistribusi normal sebagaimana yang tercantum dalam table ringkasan hasil uji normalitas di bawah ini:

Tabel 8. Ringkasan Uji Normalitas Data Peneltian

Sumber:output SPSS 16.o for windows, 2018

\begin{tabular}{|c|c|c|c|c|c|c|}
\hline \multicolumn{7}{|c|}{ Tests of Normality } \\
\hline & \multicolumn{3}{|c|}{ Kolmogorov-Smirnov $^{a}$} & \multicolumn{3}{|c|}{ Shapiro-Wilk } \\
\hline & Statistic & Df & Sig. & Statistic & Df & Sig. \\
\hline $\begin{array}{l}\text { Flypaper } \\
\text { Effect }\end{array}$ & .320 & 74 & .091 & .653 & 74 & .762 \\
\hline $\begin{array}{l}\text { Kinerja } \\
\text { Keuanga } \\
\mathrm{n}\end{array}$ & .513 & 74 & .074 & .752 & 74 & .411 \\
\hline \multicolumn{4}{|c|}{ a. Lilliefors Significance Correction } & & & \\
\hline $\begin{array}{l}\text { Sumber: } \\
2018\end{array}$ & utput SPSS & 16.0 for $w i$ & indows, & & & \\
\hline
\end{tabular}


Berdasarkan Hasil Uji Normalitas Data diatas, diketahui nilai signifikan sebesar 0.091 dan yang lebih besar dari 0.05, sehingga dapat ditarik kesimpulan bahwa data yang diuji adalah berdistribusi normal.

c.Hasil Uji Hetoroskedastisitas

Uji heteroskedastistas merupakan pengujian untuk mendeteksi ada tidaknya masalah heteroskedastistas dalam data penelitian. Jelas tergambar pada gambar 2, dapat dinayatakan bahwa model atau data penelitian ini menunjukkan tidak terjadi masalah heteroskedastisitas dalam model regresi karena tidak ada pola yang jelas, serta tergambar titiktitik yang menyebar di atas dan di bawah angka o pada sumbu Y.

Gambar 2. Grafik Hasil Uji Heterokedastisitas

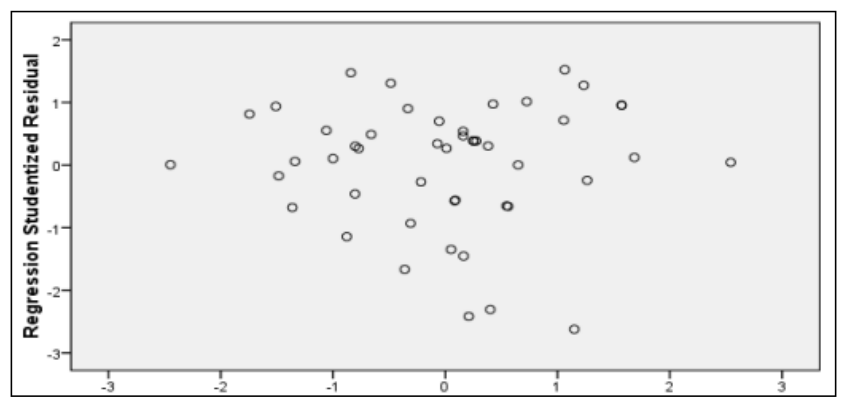

\section{Hasil Uji Analisis Regresi}

Upaya mencari hubungan sebab akibat antaravariabel independen danvariabel dependen (jika X, maka Y) dengan kata lain apakah variable independen dapat mempengaruhi variabel dependen, maka dilakukan analisis statistik inferensial dengan teknik analisis regresilinier sederhana. Berikut hasil analisis data akan ditampilkan di bawah ini.

\begin{tabular}{|l|l|l|l|}
\hline Model & $R$ & $R$ Square & Siq. \\
\hline 1 & $-0.642^{a}$ & 0.412 & 0.00 \\
\hline
\end{tabular}

\section{Model Summary}

a.Predictors: (Constant), Kinerja Keuangan

Sumber:output SPSS 16.o for windows, 2018
Berdasarkan hasil analisis regresi, dapat diketahui bahwa nilai (R) sebesar -0.642 atau 41,2\% dalam artian bahwa ada Pengaruh negatif Flypaper Effect pada Dana Alokasi Umum (DAU) Terhadap Kinerja Keuangan Pemerintah Daerah Kota Bima. Jika flypaper effect pada Dana Alokasi Umum (DAU) meningkat sebesar 1 satuan, maka kinerja keuangan Pemerintah Daerah Kota Bima akan menurun sebesar 0.642. Artinya semakin tinggi Flypaper Effect pada Dana Alokasi Umum (DAU) maka menyebabkan semakin rendahnya kinerja keuangan pemerintah daerah Kota Bima.

Dari Tabel Model Summary diatas, diketahui R Square terdapat angka 0.412 artinya bahwa Flypaper effect pada dana alokasi Umum (DAU) memberi kontribusi sebesar 0.412 (0.412 x $100 \%=41.2 \%)$ atau berkontribusi sebesar $41.2 \%$ terhadap kinerja keuangan pemerintah daerah Kota Bima, sedangkan sisanya sebesar 58.8\% dijelaskan oleh variabel lain yang tidak di teliti.

\section{Pengujian Hipotesis Penelitian}

Pengujian hipotesis dilakukan untuk mengetahui apakah variabel independen berpengaruh seginifikan terhadap variabel dependen. Dengan kata lain apakah hipotesis penelitian yang telah diajukan oleh peneliti sebelumnya pada Bab II dapat diterima atau ditolak. Berdasarkan hasil analisis regresi liner sederhana dengan menggunakan bantuan program SPSS 16.0, sehingga diketahui Sig. $0.00<0.05$, maka Ho ditolak dan Ha diterima. Artinya bahwa hipotesisi alaternatif (Ha) yang mengatakan "Ada Pengaruh Signifikan Flypaper Effect pada Dana Alokasi Umum (DAU) Terhadap Kinerja Keuangan Pemerintah Daerah Kota Bima” dapat diterima sebaliknya hipotesisi nihil (Ho) ditolak.

Kondisi terjadinya flypaper effect di suatu daerah ditunjukkan ketika tingkat ketergantungan daerah yang tinggi terhadap alokasi dana perimbangan yang di berikan oleh pemerintah pusat dalam membiayai belanja daerah. Hasil penelitian menunjukkan bahwa telah terjadi flypaper effect pada Dana Alokasi Umum di Pemerintah Kota Bima. Hai 
ini terbukti dengan besaran koefisien DAU dibandingkan dengan Pendapatan Asli Daerah (PAD). Kemudian adanya hasil dari perhitungan rasio kemandirian keuangan Daerah Kota Bima yang membentuk pola hubungan Intruktif yaitu pola dimana daerah masih belum mandiri yang mengandalkan dana transfer untuk memenuhi kebijakan kesejahteraan masyarakat, dan hasil rasio ketergantungan keuangan Pemerintah Kota Bima yang cenderung sangat tinggi dengan besaran nilai 79,9\%.

Berdasarkan hasil analisis deskriptif diketahui bahwa variable flypaper Effect pada Dana Alokasi Umum (DAU) memiliki pengaruh signifikan terhadap kinerja keuangan dibuktikan melalui nilai sig. $0.00<0.05$ dan pengaruh tersebut bersifat negative dibuktikan melalui $\mathrm{R}$ (correlation) sebesar -0.641. artinya bahwa semakin tinggi tingkat flypaper effect menunjukan semakin rendah tingkat kinerja keuangan. Setiap kali kenaikan 1 (satu) satuan nilai koefisien flypaper effect pada dana alokasi umum (DAU) maka kinerja keuangan daerah Kota Bima mengalami penurunan 0.641. Dengan artian jika tingginya Flypaper effect pada (DAU) maka semakin rendah kinerja keuangan pemerintah daerah Kota Bima.

\section{KESIMPULAN}

Berdasarkan pada teori-teori dan hasil analisis serta pembahasan mengenai pengaruh flypaper effect pada dana alokasi umum (DAU) terhadap Kinerja keuangan pemerintah daerah Kota Bima, maka dapat disimpulkan bahwa terjadi flypaper effect di Kota Bima, yang dilihat dari besaran koefisien DAU dibandingkan koefesien PAD Kota Bima. Hal ini ditunjukkan oleh terdapat pengaruh negatif dan signifikan variabel flypaper effect pada DAU terhadap variabel kinerja keuangan. Hal ini berarti, semakin tinggi Flypaper effect pada DAU maka semakin rendah kinerja keuangan pemerintah Kota Bima. Flypaper effect menyebabkan rendahnya kemandirian daerah dan selalu bergantung pada pemerintah pusat. Pemerintah pusat dianggap sebagai "the power of donatur", membuat pemerintah Kota Bima terkesan manja dalam membiayai dirinya sendiri dalam artian tidak antusias dalam pengoptimalisasi pendapatan asli daerah.

Ada pun saran yang dapat disampaikan adalah perlunya meningkatkan efektifitas dan efesiensi sertalebih berinovasi dalam pengelolaan keuangan untuk meningkatkan perolehan PAD melalui dana transfer berupa DAU. Pemerintah pusat, perlu lebih mendorong pemerintah daerah dalam mengelola keuangan dengan baik agar tidak terjadi flypaper effect di kabupaten/ kota di Indonesia. Ada baiknya pemerintah pusat membuat rekapitulasi pertahun daerahdaerah mana saja yang DAU tiap tahunnya meningkat dan diberikan teguran atau sanksi. Dengan begitu pemerintah daerah akan berusaha menekan tingginya DAU sehingga akan berusaha meningkatkan PAD, perlunya sosialisasi bahwa hakikat DAU hanya sebagai stimulan bukan sebagai sumber utama penerimaan keuangan daerah.

\section{DAFTAR PUSTAKA}

Abdullah, Sukriy dan Halim, Abdul. 2003. "Pengaruh Dana Alokasi Umum (DAU) dan Pendapatan Asli Daerah (PAD) terhadap Belanja Pemerintah Daerah Studi Kasus Kabupaten/Kota di Jawa dan Bali”. Simposium Nasional Akuntansi VI, Yogyakarta, Hal 1140-1159.

. 2004. Akuntansi Keuangan Daerah, Edisi Revisi. Jakarta: Salemba Empat . 2007. Akuntansi Sektor Publik: Akuntansi keuangan Daerah. Edisi 3. Jakarta: Salemba Empat.

Azwardi. 2007. The Impact of Fiscal Desentralization on Interregional economic Performance in Indonesia:Fiscal Decentralization. UI-Depok.

Halim, Abdul. 2002. Akuntansi Sektor Publik akuntansi Keuangan Daerah Edisi

Pertama Salemba empat, Jakarta. 
Kuncoro, Haryo. 2007. Fenomena Flypaper Effect pada Kinerja Keuangan Pemerintah Daerah Kota dan Kabupaten di Indonesia. Simposium Nasional Akuntansi X, UNHAS Makasar, 26-38 Juli 2007.

Kurnia, Eka Daddy. 2013. “Analisis Flypaper effect Berdasarkan Pemetaan Indeks Kemampuan Keuangan dan Pertumbuhan Ekonomi (Studi kasus pada kabupaten/ kota di Jawa Timur)". Jurusan Ilmu Ekonomi Fakultas Ekonomi dan Bisnis Universitas Brawijaya Malang.

Mutiara, Maimunah. 2006. Flypaper Effect Pada Dana Alokasi Umum (DAU) dan Pendapatan Asli Daerah (PAD) Terhadap Belanja Daerah Pada

Kabupaten/Kota di Pulau Sumatera. Paper disajikan pada Simposium

Nasional Akuntansi IX Padang.

Purnomo, Hermawan Bayu. 2011. "Flypaper Effect Pada Pengeluaran Transfer Tidak Bersyarat dan Pendapatan Asli Daerah Terhadap Pertumbuhan Ekonomi Daerah Kabupaten/kota di Kalimantan Tahun
2007-2010”. Fakultas Ekonomi dan Bisnis Universitas Padjajaran Bandung.

Shah, Anwar. 1991, A Practitioner's guide to ingovermental fiscal transfers, Policy Research Working Paper Series, The world Bank.

Siregar, S. (2013). Statistik Parametrik Untuk Penelitian Kuantitatif. Dilengkapi dengan perhitungan manual dan aplikasi SPSS Versi 17. PT. Bumi Aksara.

Syafri, Sofyan. 2008. Analisis Kritis Atas Laporan Keuangan. Jakarta Rajawali Pers.

Bima Dalam Angka, 2017. Katalog BPSBima:1102001.2102

\section{Sumber Bacaan dari Internet dan Bahan Lainnya}

Kepmendagri No.690.900.327 tahun 1996 tentang Penilaaian Kinerja Keuangan.

www.kemenkeu.go.id 